\title{
Transmission Mechanism of Monetary Policy Channels and Economic Growth in Ethiopia: Cointegration and Causality Analysis Approach
}

\author{
Abebew Aklog Asmare ${ }^{1 *}$ \\ Department of Statistics, College of Natural and Computational Science, \\ Mekdela Amba University, Tuluawulia, Ethiopia \\ Yitateku Adugna Agmas ${ }^{1}$ \\ Department of Rural Development and Agricultural Extension, College of Agriculture and Natural Resource, \\ Mekdela Amba University, Tuluawulia, Ethiopia
}

\begin{abstract}
This paper aims to investigate the relationship between transmission mechanism of monetary policy channel and economic growth in Ethiopia. Johansson co-integration, vector error correction model (VECM), Granger causality test were utilized for a time series data collected from 1972 to 2018. Broad money supply, real effective exchange rate and deposit interest rate have positive and domestic credit has negative effect on real economic growth in the long-run whereas in the short run broad money supply, real effective exchange rate have positive but, domestic credit and deposit interest rate have negative relationship with real economic growth. Real economic growth, broad money supply, domestic credit and real effective exchange rate have bidirectional causality whereas deposit interest rate has one directional causality with real economic growth, broad money supply, domestic credit and real effective exchange rate. Monetary policy transmission mechanisms channels are most important in promoting real economic growth in Ethiopia through creation of modern banking sector, so as to enhance domestic investment, the instrument to increase output per capital and hence promoting economic growth in the long-run.
\end{abstract}

Keywords: Granger Causality, Johansson Co-integration, Monetary Policy, Time Series, Vector Error Correction Model (VECM)

DOI: $10.7176 /$ RHSS/12-1-03

Publication date: January $31^{\text {st }} 2022$

\section{Introduction}

Monetary policy is the process by which the regulatory authorities, government and central bank of a country controls the rate of inflation, exchange rate, supply of money and rate of interest in order to achieve a set of objectives that is advantageous for the strength, stability and growth of the economy [1].

The conduct of monetary policy in Ethiopia has gone through two distinct phases, before 1991 and after 1991. From 1974 to 1991, since the country is under the regime of Derg, military power, the monetary policy was designed to target of central plan. So, the country inherited a structurally weak economy characterized by extensive regulations in the financial, production and international trade. Thus monetary policy was relatively inactive. In 1990/91 following the fall of the autocratic government, EPRDF came to power with the idea of market oriented economy up on the adjustment programs of the international monetary fund and the world bank. The inception of economic reforms in the 1990s, however, saw the economy transform to a market-based system for promoting economic growth through agricultural farms, industries, financial institutions and banks are under its direct control. In such a way the central bank controls monetary policy variables on behalf of the government [2].

The classical economists' view of monetary policy is based on the quantity theory of money. The quantity theory of money states that the velocity of circulation of money supply equal to current nominal gross domestic product $[3,4]$. Keynesians believe that expansionary monetary policy increases the supply of loan able funds available through banking system, causing interest rates to fall. With lower interest rate, aggregate expenditures on investment and interest-sensitive consumption goods usually increase, causing real GDP to rise, whereas monetarists argue that in short run expansionary monetary policies may increase the level of real GDP by increasing aggregate demand. However, in the long-run, when the economy is operating at the full employment level, they argue that the quantity theory remains a good approximation of the link between the supply of money, price level, and the real GDP.

The qualification of monetary policy to influence economic activity is still limited in developing countries, with low levels of economic monetization [5]. So monetary aggregate channel is important in monetary policy transmission mechanism in Ethiopia. However, for a variety of reasons, the link between monetary policy instruments and aggregate demand, the monetary transmission mechanism may be significantly weaker in lowincome countries like Ethiopia than it is in advanced and emerging economies.

In developing economies where most of the projects are financed by bank loans, the bank lending channel is 
more effective in explaining the variation in output. Monetary policy affects output through the bank credit channel is increasingly accepted. Recent developments in the global economy have shown emphatically that the freezing up of bank credit has large negative effects on GDP. Therefore bank lending channel is likely to be the dominant channel of monetary policy transmission, but its effectiveness, which depends on the domestic institutional context, the structure of the banking system, and the intrinsic stability of the domestic macroeconomic environment, is a problem. Thus, focusing on bank credit appears to be the right way to look at the monetary transmission mechanism [6].

Monetary policy is one of the least understood economic processes, but yet the successful conduct of monetary policy requires a clear understanding of the process by which changes in monetary policy affect the economy. Therefore the efficiency of the monetary policy depends on the ability of policy makers to make an accurate assessment of the timing and the effect of the policy on economic activities [7].

Momentary transmission mechanisms in developed countries focus on prices (interest rate, exchange rate) rather than quantities (credit, base money, money supply). In distinction, the popular orthodoxy of monetary transmission mechanism in low-income countries has been its focus on quantities rather than prices, this difference is often attributed to weak institutional frameworks, oligopolistic banking structure, shallow financial markets, and extensive central bank intervention in foreign exchange markets in low-income countries [8].

A methodological understanding of the dynamics of GDP and monetary instrument is important in order to undertake the appropriate monetary policy decisions. Therefore, to solve monetary policy analytically by using econometric model with appropriate force and right direction; policy makers need to have a clear understanding of the propagation mechanism of the monetary policy shock and the relative importance of the various channels, namely money, interest rates, domestic credit and exchange rates in affecting the real sectors of the economy. Assessing the empirical effectiveness of monetary policy on economic growth in Ethiopia is therefore an important topic for this research.

To the best of the researcher knowledge, there have been no more empirical studies done on the causal relationship between transmission mechanism of monetary policy channels and economic growth in the country.

A study conducted by [2] ARDL Co - Integration Approach on Effect of Monetary Policy on the Private Sector Investment in Ethiopia for the period of 1975-2011. The results suggest that private investment is positively and significantly influenced in the short-run by public investment, money supply, and a real output but negatively and significantly by real exchange rate while, real interest rate is found to have insignificant and has a negative sign in line with macro-economic theory. Moreover, in the long run, the result shows a positive and significant effect of public investment, real GDP and broad money supply while real exchange rate negatively and significantly influenced private investment.

A study conducted by [9] cointegration approach on the impact of long-run impact of credit on economic growth of Ethiopia from the period 1971-2011. The results supported a positive and statistically significant equilibrium relationship between bank credit and economic growth in Ethiopia.

While [4] empirical study aimed to examine the share of money supply in explaining the dynamics of inflation in Ethiopia, using Error Correction Model by employing time series data set for the period ranging from 1974/75 to 2014/15. The Johansson's Maximum likelihood approach for cointegration has indicated the existence of long run relationships among variables entered the inflation model.

The study conducted by [10] the impact of monetary policy on the economic development in Lao PDR by using annual time series data from 1989-2016. The finding shows that money supply, interest rate, and inflation rate are negatively effect on the real GDP per capita in the long run and only the real exchange rate has a positive sign. The error correction model result indicates the existence of short-run causality between money supply, real exchange rate and real GDP per capita.

According to [11] study suggests effectiveness of monetary policy transmission channel in Nigeria using VAR and VECM with annual time series data from 1981-2015. The result shows that money supply, interest rate, lending rate channel does not determine the RGDP as there is no causality, unidirectional causality was found on financial sector, exchange rate, trade balance rate and CPI, exchange rate granger causes lending rate and RGDP.

According to [12] the study seeks to assess the impact of relationship between Money Supply and Per Capita GDP Growth Rate in Bangladesh over the period 1972-2014 with a VECM model. The model is specified with three variables, namely, the percentage of Broad Money to GDP (BMGDP), the Real Interest Rate (RIR) and the Annual per Capital GDP Growth Rate (GDPGR). Findings suggest that steady BMGDP is associated with GDPGR and money supply has important impact on the growth rate of output in the long run.

The study conducted by [13] on the annual series data from 2000 to 2016 is applied to analyze the relationship between the money supply $\left(M_{2}\right)$ and the macroeconomic variables (the real GDP, the inflation rate $\&$ the interest rate) under the vector auto regression (VAR) model in China. From empirical analysis, an increase in the real GDP can result in an increase in the money supply; also, an increase in the inflation rate can lead to an increase in the money supply; conversely, an increase in the interest rate can cause a decrease in the money supply.

The study examine by [14] on the relative importance of the different channels of the monetary transmission 
mechanism in Zambia. Vector Autoregressive Methods are used to examine the strength of each channel of monetary policy, namely interest rate, Exchange rate, credit and asset price channels. Results indicate that the exchange rate and credit are effective channels of monetary policy transmission in Zambia.

The study conducted by [15] on time series data covering 1986 to 2016. The study adopted an Ordinary Least Squared technique and also conducted the unit root and co-integration tests. The study showed that long run relationship exists among the variables. In addition, the core finding of this study showed that monetary policy rate, interest rate, and investment have insignificant positive effect on economic growth in Nigeria. Money supply however has significant positive effect on growth in Nigeria. Exchange rate has significant negative effect on GDP in Nigeria.

Unlike the above studies, in this study the causal relationship between real interest rate, real exchange rate, domestic credit and broad money supply on economic growth and between transmission mechanisms of monetary policy channel were examined by using VAR and Error Correction Model for the period 1972 up to 2018.

\section{Objectives of the Research}

The main objective of this study was to investigate the relationship between transmission mechanism of monetary policy channel and economic growth in Ethiopia with the application of multivariate time series analysis approach from 1972 to 2018. Specifically this paper was investigate the direction of causality between transmission mechanism of monetary policy channels and economic growth in Ethiopia and test the condition of the short-run and long-run relationship between transmission mechanisms of monetary policy channels and economic growth in the country.

\section{Research Methodology}

\subsection{Study Variables}

This study focused on the relationship between transmission mechanism of monetary policy channel and real economic growth in Ethiopia based on secondary data which was collected from 1972 to 2018 including the variables Broad Money Supply $\left(\mathrm{M}_{2}\right)$, Domestic Credit (DC), Real Effective Exchange Rate (REER) and Deposit Interest Rate (DIR) as a proxy of transmission mechanism of monetary policy channel and Real Gross Domestic Product (RGDP) as a proxy of real economic growth. The five variables are transformed to logarithmic form to obtain $\mathrm{LNM}_{2}$, LNDC, LNREER, LNDIR and LNRGDP respectively over the period 1972 to 2018. Transforming data to logarithmic form have advantage of smoothing data distribution to some extent and makes data to have better goodness of fit for non-linearity. The variables are obtained from World development indicator at World Bank dataset.

\subsection{Statistical Model}

A VECM is a restricted VAR model designed to test the cointegration in the system of I (1) series. The reducedform of VAR model used in this study was adopted and modified form that of Tran (2018) [16] and presented as follows:

$$
Y_{t}=V+A_{1} Y_{t-1}+A_{2} Y_{t-2}+\cdots+A_{p} Y_{t-p}+\varepsilon_{t}
$$

Where $t=1,2, \ldots, T, A_{i}$ are $(5 \times 5)$ fixed coefficient matrix, $V=\left(V_{1}, V_{2}, \ldots, V_{5}\right)^{\prime}$ is a fixed an $(5 \times 1)$ vector of intercept terms allowing for the possibility of a non-zero mean $E\left(Y_{i}\right)$ and $\varepsilon_{t}=$ $\left(\varepsilon_{1}, \varepsilon_{2}, \ldots, \varepsilon_{5}\right)^{\prime}$ is an $(5 \times 1)$ matrix of unobservable zero mean white noise vector process (serially uncorrelated or independent) with time invariant covariance matrix $\Sigma$. When I(1) variables are cointegrated, the VAR model can be expressed by first error correction form as below. $B X_{t}+\varepsilon_{t}$

$$
\Delta Y_{t}=\pi Y_{t-1}+\sum_{i=1}^{p-1} \Gamma_{i} \Delta Y_{t-i}+
$$

Is known as Vector Error Correction Model (VECM), where $\pi=-I_{n}+\sum_{i=1}^{p} A_{i}, I_{n}$ is the identity, matrix, and $\Gamma_{i}=-\sum_{j=i+1}^{p} A_{j}$. The above specification of VECM contains information on both short and long run adjustment to change in $Y_{t}$ through estimating $\Gamma$ and $\pi$ respectively. Matrix $\pi$ can be decomposed as $\pi=\alpha \beta^{\prime}$, where $\alpha$ is $n \times r$ matrix of speed of adjustment towards the long run equilibrium and $\beta$ is an $n \times r$ matrix of parameters which determines the cointegration relationship of the long-run coefficients such that $\beta^{\prime} Y_{t-n}$ represents multiple cointegration relationships, the columns of $\beta$ are interpreted as long - run equilibrium relationship between variables.

Instead of identifying the vector error correction coefficients, identification focuses on the errors of the system. In the applications of $[17,18]$ the innovations of VECM were orthogonalzed using a Choleski decomposition of the covariance matrix. A recursive structure was imposed on the instantaneous relations between the variables thus are Granger Causality, Impulse Response Function and Forecast Error Variance Decompositions (FEVDs) 


\section{Empirical Results}

The unit root test should be carried out before running the model to avoid spurious regression [16]. A variable is considered to be stationary if the null hypothesis of a unit root is rejected. A time trend should be included, because the exchange rate and oil price seem to steadily rise over time. The standard Augmented Dickey-Fuller (ADF) and the Philip Peron (PP) unit root test will be used to examine the stationary properties for the long run relationship of the times series variables [19].

Table 4.1. Unit Root Test of the Series at Level

\begin{tabular}{l|l|l|l|l|l|l}
\hline \multirow{2}{*}{ Series } & \multicolumn{2}{|l|}{ Level with intercept } & \multicolumn{2}{l}{ Level with intercept and trend } & \multicolumn{2}{l}{$\begin{array}{l}\text { Level with without intercept } \\
\text { and trend }\end{array}$} \\
\cline { 2 - 7 } & \multicolumn{2}{|l|}{ Test statistics and the value in the bracket are the critical values at 5\% significance level } \\
\cline { 2 - 7 } & ADF & PP & ADF & PP & ADF & PP \\
\hline LNRGDP & $3.569(-2.94)$ & $3.569(-2.94)$ & $0.724(-3.52)$ & $0.724(-3.52)$ & $4.187(-1.95)$ & $4.187(-1.95)$ \\
LNM & 2 \\
LNDC & $3.826(-2.94)$ & $3.826(-2.94)$ & $2.061(-3.52)$ & $2.061(-3.52)$ & $11.62(-1.95)$ & $11.62(-2.95)$ \\
LNREER & $1.921(2.94)$ & $1.921(-2.94)$ & $0.273(-3.52)$ & $0.273(-3.52)$ & $8.347(-1.95)$ & $8.347(-2.95)$ \\
LNDIR & $-1.76(-2.94)$ & $-1.76(-2.94)$ & $-1.96(-3.52)$ & $-1.96(-3.52)$ & $-0.485(-1.95)$ & $-0.485(2.95)$ \\
& $-2.14(-2.94)$ & $-2.14(-2.94)$ & $-2.05(-3.52)$ & $-2.05(-3.52)$ & $-0.282(-1.95)$ & $-0.282(-$ \\
\hline \hline
\end{tabular}

Note: The series are all non-stationary at level; The time series defined as; RGDP: Real Gross Domestic Product; BM: Broad Money; DC: Domestic Credit; REER: Real Effective Exchange Rate and DIR: Deposit interest rate with log transformations of all series in this study.

Table 4.2. Unit Root Test of the Log Series at First Differences.

\begin{tabular}{|c|c|c|c|c|c|c|}
\hline \multirow[b]{3}{*}{ Series } & \multicolumn{2}{|c|}{ Differenced with intercept } & \multicolumn{2}{|c|}{$\begin{array}{l}\text { Differenced with Trend and } \\
\text { Intercept }\end{array}$} & \multicolumn{2}{|c|}{$\begin{array}{ll}\text { Differenced } & \text { without } \\
\text { intercept and trend }\end{array}$} \\
\hline & \multicolumn{6}{|c|}{ Test statistics and the value in the bracket are the critical values at $5 \%$ significance level } \\
\hline & $\mathrm{ADF}$ & PP & ADF & PP & ADF & PP \\
\hline LNRGDP & $-5.51(-2.94)$ & $-5.51(-2.94)$ & $-6.93(-3.52)$ & $-6.93(-3.52)$ & $-4.50(-1.95)$ & $-4.50(-1.95)$ \\
\hline $\mathrm{LN} M_{2}$ & $-3.97(-2.94)$ & $-3.97(-2.94)$ & $-5.12(-3.52)$ & $-5.12(-3.52)$ & $-2.33(-1.95)$ & $-2.33(-1.95)$ \\
\hline LNDC & $-5.24(2.94)$ & $-5.24(-2.94)$ & $-5.30(-3.52)$ & $-5.30(-3.52)$ & $-2.98(-1.95)$ & $-2.89(-1.95)$ \\
\hline LNREER & $-8.23(-2.94)$ & $-8.23(-2.94)$ & $-8.20(-3.52)$ & $-8.20(-3.52)$ & $-8.30(-1.95)$ & $-8.30(-1.95)$ \\
\hline \multirow[t]{2}{*}{ LNDIR } & $-6.16(-2.94)$ & $-6.16(-2.94)$ & $-9.12(-3.52)$ & $-9.12(-3.52)$ & $-6.23(-1.95)$ & $-6.23(-1.95)$ \\
\hline & \multicolumn{2}{|l|}{ Stationary } & \multicolumn{2}{|l|}{ Stationary } & \multicolumn{2}{|l|}{ Stationary } \\
\hline
\end{tabular}

Note: The series are all stationary at first log differenced; The time series defined as; LNRGDP: log Real Gross Domestic Product; $\mathrm{LNM}_{2}$ : log Broad Money; LNDC: log Domestic Credit; LNREER: log Real Exchange Rate; LNDIR: $\log$ deposit interest rate.

From table 4.2, the first difference of the unit root test is rejected after the series are transformed with natural logarithms and hence all the series are significant at 5\% significance level, concluding that all variables are stationary at first difference and integrated of order I(1).

Before cointegration analysis and Vector Error correction Model (VECM) are tested optimal lag length test is preceded. In this study, determination of optimal lag order is performed using the Akaike information criterion (AIC), Schwarz information criterion [20], and Hannan-Quin(HQ) information criterion. In each criterion, the lag with a minimum criterion value is selected as an optimum lag length for the model. The results are shown in Table 4.3 below. Therefore, from Table 4.3, the AIC, SBIC and HQIC test suggest the appropriate lag length for the model to be one (1), since the minimum AIC, SBIC, HQIC and FPE values occur at lag one.

Table 4.3: VAR Lag Order Selection Results.

\begin{tabular}{l|l|l|l|l}
\hline Lags & AIC $(\mathrm{m})$ & SBIC $(\mathrm{m})$ & HQIC $(\mathrm{m})$ & FPE $(\mathrm{m})$ \\
\hline \hline 1 & $-7.57357^{*}$ & $-8.81476^{*}$ & $-8.35981^{*}$ & $1.0 \mathrm{e}-10^{*}$ \\
2 & -5.96204 & -8.23756 & -7.40349 & $1.9 \mathrm{e}-10$ \\
3 & -5.29408 & -8.60392 & -7.39073 & $1.5 \mathrm{e}-10$ \\
4 & -5.36876 & -8.71293 & -7.12062 & $1.9 \mathrm{e}-10$ \\
5 & -3.80729 & -8.18579 & -6.21436 & $5.4 \mathrm{e}-10$ \\
\hline
\end{tabular}

* Indicates that the VAR order selected by the Criterion

Lag exclusion test carries out confirmation for suitability of each lag selected by the above three criteria for the VAR. For each lag, the Chi square $X^{2}$ (Wald) statistics of all variables are reported separately and jointly. As it can be seen from Table 4.4, lag one is significant for the five and joint series at $5 \%$ significance level. Therefore, provided that VEC models usually need the same lag length for all the series, the chi-square test assures 
that VEC (1) is found optimal for the data set and hence could be take on.

Table 4. 4: VAR Lag Exclusion Wald Test.

Chi-squared test statistics for lag exclusion: number inside the bracket is p-values

\begin{tabular}{l|l|l|l|l|l|l}
\hline \hline Lags & LNRGDP & LNM $_{2}$ & LNDC & LNREER & LNDIR & ALL \\
\hline Lag 1 & 30.697 & 54.975 & 51.126 & 18.419 & 33.338 & 199.470 \\
& $(0.000)$ & $(0.000)$ & $(0.000)$ & $(0.000)$ & $(0.000)$ & $(0.000)$ \\
\hline Lag & 1.220 & 7.236 & 6.872 & 4.725 & 1.126 & 25.056 \\
& $(0.943)$ & $(0.204)$ & $(0.230)$ & $(0.450)$ & $(0.954)$ & $(0.460)$ \\
\hline \hline DF. & 5 & 5 & 5 & 5 & 5 & 25 \\
\hline
\end{tabular}

So far it is noticed that all series in the study are integrated of order one. This fact leads the way for the necessity of co-integration test to see the existence of a linear combination(s) of the five variables which is (are) stationary (I (1)). To determine the number of co-integrating relationships, Johansen (1995) approach of cointegration test is applied. The two tests for co-integration are trace test and the maximum eigenvalue statistics were applied in this paper. From the result of Johansen co-integration test presented in table 4.4, can be shown that trace test (LR statistic) (103.77) exceeds with the respective critical value (70.60). The maximum eigenvalue test also supports the same thing as trace test with estimated LR statistic (56.59) exceeds with the respective critical value (33.37). This implies that the null hypothesis of no co-integration relations is rejected at $5 \%$ significance level in favor of the alternative one which states that there exists one co-integration.

Table 4.5: Johansson Co-integration Test Results.

\begin{tabular}{|c|c|c|c|c|c|}
\hline \multirow[t]{2}{*}{$H_{o}:$} & \multirow[t]{2}{*}{ Eigenvalue } & \multicolumn{2}{|c|}{ Trace Test } & \multicolumn{2}{|c|}{ Maximum Eigenvalue Test } \\
\hline & & Statistic & Critical Value & Statistic & Critical value \\
\hline$r<4$ & 0.724 & 1.02 & 8.18 & 1.02 & 8.18 \\
\hline$r<3$ & 0.358 & 11.32 & 17.95 & 10.30 & 14.90 \\
\hline $\begin{array}{l}r=5 \\
x<2\end{array}$ & 0.311 & 27.70 & 31.52 & 16.38 & 21.07 \\
\hline$r \leq 2$ & 0.209 & 47.18 & 48.28 & 19.48 & 27.14 \\
\hline$r \leq 1$ & 0.023 & 103.77 & 70.60 & 56.59 & 33.32 \\
\hline$r=0 *$ & & & & & \\
\hline
\end{tabular}

*indicates that rejection of the hypothesis at $5 \%$ level of significances.

Eigenvectors, normalized to first column: (These are the co-integration relations)

\begin{tabular}{lcccc} 
LNRGDP & LNM & LNDC & LNREER & LNDIR \\
1.000 & -0.542 & 0.337 & -0.036 & -0.237 \\
\hline
\end{tabular}

Consequently, the co-integrating vector is given by

$$
\beta=(1,-0.542,0.337,-0.036,-0.237)
$$

The values correspond to the co-integrating coefficients of logarithm of Real Economic Growth (normalized to one), logarithm of transmission mechanisms of monetary policy channel (Broad Money, Domestic Credit, Real Effective Exchange Rate and Deposit Interest Rate) respectively. Thus, the vector can be expressed in equation [5.1] as:

$$
L N R G D P_{t}=0.542 L_{N} M_{2, t}-0.337 L N D C_{t}+0.036 L N R E E R_{t}+0.237 L N D I R_{t}
$$

Based on the co-integration equation (4.1) the long-run elasticity of real economic growth with respect to broad money supply, real effective exchange rate and deposit interest rate are positive and it is negative for domestic credit. And hence broad money supply, real effective exchange rate and deposit interest rate have positive relationship, whereas domestic credit has negative relationship with real economic growth in the long-run.

Since the cointegration test confirmed the existence of long run relationship among the variables, the vector error correction model helps to estimate the short run relationship and the speed of adjustment towards long run equilibrium. The adjustment coefficients presented in table 4.6 is the error correction terms for the co-integration vector. They measure the short-run adjustments of the deviations of the endogenous variables from their long- run values. Those coefficients identify the fraction of the long-term gap that is closed by each endogenous variable in each period (annual). In another expression, the coefficient provide information on the short run disequilibria percentage adjustment of each endogenous variable within one period of time (year in this study).

From table 4.6, the long-run and the short-run estimates of the VECM were related by the adjustment coefficients $\alpha=-(0.089,0.136,0.050,0.085)$ are negative and significant at a given significance level and reveals that the economy converges back to the long-run equilibrium. Therefore, it ascertain that $8.9 \%, 13.6 \%$, $5.0 \%$ and $8.5 \%$ of the long term gaps are closed by natural logarithm of real economic growth, natural logarithm of broad money, natural logarithm of domestic credit and natural logarithm of real effective exchange rate respectively within a year. That is $8.9 \%, 13.6 \%, 5.0 \%$ and $8.5 \%$ of the short run disequilibrium in natural logarithm of real economic growth, natural logarithm of broad money, natural logarithm of domestic credit and natural logarithm of real effective exchange rate are adjusted within one year respectively. Whereas in short run broad 
money supply, domestic credit and deposit interest rate have positive relationship with real economic growth and real effective exchange rate have negative relationship.

Table 4.6: VECM (1) estimation results

\begin{tabular}{|c|c|c|c|c|c|}
\hline Error Correction & D(LNRGDP) & $\mathrm{D}\left(\mathrm{LN} M_{2}\right)$ & $\overline{\mathrm{D} \text { (LNDC) }}$ & D(LNREER) & $\overline{\mathrm{D}(\mathrm{LNDIR})}$ \\
\hline $\begin{array}{l}\text { Adjustment } \\
\text { Coefficients }\end{array}$ & $\begin{array}{l}-0.08891 \\
(-2.351) \\
{[0.0232]}\end{array}$ & $\begin{array}{l}-0.13596 \\
(-2.470) \\
{[0.0174]}\end{array}$ & $\begin{array}{l}-0.04986 \\
(-2.059) \\
{[0.0453]}\end{array}$ & $\begin{array}{l}-0.08453 \\
(-2.200) \\
{[0.0330]}\end{array}$ & $\begin{array}{l}-0.17983 \\
(-3.112) \\
{[0.0035]}\end{array}$ \\
\hline D(LNRGDP(-1)) & $\begin{array}{l}-0.07143 \\
(-3.908) \\
{[<0.001]}\end{array}$ & $\begin{array}{l}0.12133 \\
(3.938) \\
{[<0.001]}\end{array}$ & $\begin{array}{l}0.12428 \\
(2.965) \\
{[<0.001]}\end{array}$ & $\begin{array}{l}0.07070 \\
(3.696) \\
{[<0.001]}\end{array}$ & $\begin{array}{l}0.04957 \\
(4.708) \\
{[<0.001]}\end{array}$ \\
\hline $\mathrm{D}\left(\mathrm{LN} M_{2}(-1)\right)$ & $\begin{array}{l}0.10838 \\
(2.158) \\
{[0.0371]}\end{array}$ & $\begin{array}{l}0.02467 \\
(3.570) \\
{[<0.001]}\end{array}$ & $\begin{array}{l}-0.13446 \\
(-7.520) \\
{[<0.001]}\end{array}$ & $\begin{array}{l}-0.03631 \\
(-2.480) \\
{[0.0174]}\end{array}$ & $\begin{array}{l}0.08175 \\
(2.255) \\
{[0.0298]}\end{array}$ \\
\hline $\mathrm{D}(\operatorname{LNDC}(-1))$ & $\begin{array}{l}0.06573 \\
(2.122) \\
{[0.0402]}\end{array}$ & $\begin{array}{l}0.08718 \\
(5.075) \\
{[<0.001]}\end{array}$ & $\begin{array}{l}0.14164 \\
(2.276) \\
{[0.0282]}\end{array}$ & $\begin{array}{l}0.09232 \\
(2.301) \\
{[0.0268]}\end{array}$ & $\begin{array}{l}-0.08098 \\
(-2.122) \\
{[0.0402]}\end{array}$ \\
\hline D(LNREER(-1)) & $\begin{array}{l}-0.10824 \\
(-7.793) \\
{[<0.001]}\end{array}$ & $\begin{array}{l}0.21468 \\
(2.400) \\
{[0.0213]}\end{array}$ & $\begin{array}{l}0.12858 \\
(4.171) \\
{[<0.001]}\end{array}$ & $\begin{array}{l}-0.38464 \\
(-2.168) \\
{[0.0302]}\end{array}$ & $\begin{array}{l}-0.14766 \\
(-2.032) \\
{[0.040]}\end{array}$ \\
\hline D(LNDIR(-1)) & $\begin{array}{l}-0.53057 \\
(-1.057) \\
{[0.2904]}\end{array}$ & $\begin{array}{l}-0.10462 \\
(-0.076) \\
{[0.9396]}\end{array}$ & $\begin{array}{l}0.09894 \\
(0.277) \\
{[0.7817]}\end{array}$ & $\begin{array}{l}0.35483 \\
(0.739) \\
{[0.4602]}\end{array}$ & $\begin{array}{l}0.18079 \\
(1.030) \\
{[0.3028]}\end{array}$ \\
\hline Constant & $\begin{array}{l}-0.17983 \\
(-0.697) \\
{[0.4857]}\end{array}$ & $\begin{array}{l}-0.45202 \\
(-2.217) \\
{[0.0325]}\end{array}$ & $\begin{array}{l}0.10968 \\
(0.128) \\
{[0.8980]}\end{array}$ & $\begin{array}{l}-0.44694 \\
(-0.313) \\
{[0.7540]}\end{array}$ & $\begin{array}{l}-0.79058 \\
(-0.460) \\
{[0.6457]}\end{array}$ \\
\hline
\end{tabular}

Table 4.7: Pair-wise Granger-causality tests of lag: 1

\begin{tabular}{|c|c|c|c|}
\hline Null hypothesis & Obs. & F-Statistic & Prob. \\
\hline $\begin{array}{l}\text { LNM } M_{2} \text { does not granger cause LNRGDP } \\
\text { LNRGDP does not granger cause } \mathrm{LNM}_{2}\end{array}$ & $\begin{array}{l}47 \\
47\end{array}$ & $\begin{array}{l}18.006 \\
144.28\end{array}$ & $\begin{array}{l}<<0.001 \\
<0.001\end{array}$ \\
\hline $\begin{array}{l}\text { LNDC does not granger cause LNRGDP } \\
\text { LNRGDP does not granger cause LNDC }\end{array}$ & $\begin{array}{l}47 \\
47 \\
\end{array}$ & $\begin{array}{l}31.124 \\
61.396 \\
\end{array}$ & $\begin{array}{l}<<0.000 \\
<0.000\end{array}$ \\
\hline $\begin{array}{l}\text { LNREER does not granger cause LNRGDP } \\
\text { LNRGDP does not granger cause LNREER }\end{array}$ & $\begin{array}{l}47 \\
47 \\
\end{array}$ & $\begin{array}{l}17.933 \\
38.805 \\
\end{array}$ & $\begin{array}{l}<<0.001 \\
<0.001 \\
\end{array}$ \\
\hline $\begin{array}{l}\text { LNDIR does not granger cause LNRGDP } \\
\text { LNRGDP does not granger cause LNDIR }\end{array}$ & $\begin{array}{l}47 \\
47\end{array}$ & $\begin{array}{l}8.718 \\
2.483\end{array}$ & $\begin{array}{l}0.013 \\
0.289 \\
\end{array}$ \\
\hline $\begin{array}{l}\mathrm{LN} M_{2} \text { does not granger cause LNDC } \\
\text { LNDC does not granger cause LNM }\end{array}$ & $\begin{array}{l}47 \\
47\end{array}$ & $\begin{array}{l}122.87 \\
64.377\end{array}$ & $\begin{array}{l}<0.001 \\
<0.001\end{array}$ \\
\hline $\begin{array}{l}\text { LNM } M_{2} \text { does not granger cause LNREER } \\
\text { LNREER does not granger cause LNM } M_{2} \\
\end{array}$ & $\begin{array}{l}47 \\
47\end{array}$ & $\begin{array}{l}27.914 \\
41.677\end{array}$ & $\begin{array}{l}<0.001 \\
<0.001\end{array}$ \\
\hline $\begin{array}{l}\mathrm{LN} M_{2} \text { does not granger cause LNDIR } \\
\text { LNDIR does not granger cause } \mathrm{LN} M_{2}\end{array}$ & $\begin{array}{l}47 \\
47\end{array}$ & $\begin{array}{l}0.872 \\
6.627\end{array}$ & $\begin{array}{l}0.646 \\
0.036\end{array}$ \\
\hline $\begin{array}{l}\text { LNDC does not granger cause LNREER } \\
\text { LNREER does not granger cause LNDC }\end{array}$ & $\begin{array}{l}47 \\
47\end{array}$ & $\begin{array}{l}13.914 \\
12.768\end{array}$ & $\begin{array}{l}0.005 \\
0.006\end{array}$ \\
\hline $\begin{array}{l}\text { LNDC does not granger cause LNDIR } \\
\text { LNDIR does not granger cause LNDC }\end{array}$ & $\begin{array}{l}47 \\
47 \\
\end{array}$ & $\begin{array}{l}1.084 \\
11.214 \\
\end{array}$ & $\begin{array}{l}0.582 \\
0.008 \\
\end{array}$ \\
\hline $\begin{array}{l}\text { LNREER does not granger cause LNDIR } \\
\text { LNDIR does not granger cause LNREER }\end{array}$ & $\begin{array}{l}47 \\
47 \\
\end{array}$ & $\begin{array}{l}1.746 \\
9.194 \\
\end{array}$ & $\begin{array}{l}0.233 \\
0.012 \\
\end{array}$ \\
\hline
\end{tabular}

Granger causality test is considered a useful technique for determining whether one time series is good for forecasting the other. Table 4.7 present's results from the pair wise Granger causality tests at 5\% significance level. The result shows that at 95\% confidence level, real economic growth, broad money supply, domestic credit and real effective exchange rate have instantaneous causality with each other. Deposit interest rate has causality with real economic growth, broad money supply, domestic credit and real effective exchange rate, but not instantaneous causality. 


\section{Discussion}

In this study multivariate time series analysis modeling was used to investigate the relationship between real gross domestic product as a proxy of economic growth and broad money supply, domestic credit, real effective exchange rate and deposit interest rate as an indicator of transmission mechanism of monetary policy channel.

Based on the Johansson co-integration test of the long-run relationship broad money supply, real effective exchange rate and deposit interest have positive relationship with real economic growth This result convince with the study [21], [14] in Bangladesh and Zambia respectively, but domestic credit has negative relationship with real economic growth in the long-run, the possible reason for this study is; for developing country credit view of monetary policy will have a greater effect on expenditure by smaller firms, which are more dependent on bank loans than it will on large firms, which can access the credit markets directly through stock and bond markets (and not only through banks). Apart from being forced to cut their loans supply, banks generally increase their lending rate which in turn raises external finance premium, and then output will decline. In this case, increase in lending rates is a way in which banks try to compensate for borrowers attitude to exhibit stronger adverse selection and moral hazard behavior through monetary contraction, the study conducted by (Anowor and Okorie, 2016) in Nigeria, domestic credit has postive realtionship with real economic growth.

VECM result indicates the existence of short-run causality between broad money supply, real economic growth, domestic credit, real effective exchange rate and deposit interest rate. Broad money supply, domestic credit, real effective exchange rate and real economic growth have bi-directional short-run causality. This study convince with the study conducted by $[12,14]$ in Lao Pad and Zambia respectively.

From the result of granger causality test real economic growth, broad money supply, domestic credit and real effective exchange rate have bidirectional causality. This result consistent with [22], [11] in Ruanda and Nigeria respectively.

\section{Policy Recommendations}

Based on the finding from this study the following recommendation was forwarded for the concerned body such as governments and national bank authorities of Ethiopia. Expansionary monetary policy should be formulated that will increase the amount of money supply, encourage borrowings and savings. This will expand commercial banks and other credit granting financial institutions which will encourage real investment in the economy to increase the real output. Monetary policy authorities of Ethiopia and Policy makers should focus attention on longrun policies to promote economic growth- creation of modern banking sector, so as to enhance domestic investment, the instrument to increase output per capital and hence promoting economic growth in the long-run.

\section{Acknowledgement}

Not Applicable.

\section{Funding}

No funding was available for this study.

\section{Availability of data and materials}

The datasets used for this study are available from World Development Indictor (WDI) website [databank.worldbank.org]

\section{Abbreviations}

ARDL: Autoregressive Distributed Lag, EPRDE: Ethiopian people Revolution Democracies Front, GDP: Growth Domestic Product, RGDP: Real Growth Domestic Product

\section{Reference}

1. Ayub, S. and F.M. Shah, Impact of monetary policy on gross domestic product (GDP). Asian Journal of Business and Management, 2015. 3(6).

2. Hailu, D.B. and F. Debele, The Effect of Monetary Policy on the Private Sector Investment in Ethiopia: ARDL Co-Integration Approach. Economics, 2015. 4(2): p. 22.

3. Hetzel, R., The contributions of Milton Friedman to economics. 2007.

4. Alemu, W.M. and M. Yilkal Wassie, Monetary Policy and Inflation Dynamics in Ethiopia: An Empirical Analysis. Global Journal of Human-Social Science Research, 2017. 16(4).

5. Srithilat, K., G. Sun, and M. Thavisay, The impact of monetary policy on economic development: Evidence from Lao PDR. Global Journal of Human-Social Science Research, 2017. 2: p. 9-15.

6. Khan, M.S., The design and effects of monetary policy in Sub-Saharan African countries. Journal of African Economies, 2011.20(suppl_2): p. ii16-ii35.

7. Hameed, D., Impact of monetary policy on gross domestic product (GDP). Interdisciplinary journal of 
contemporary research in business, 2010. 3(1): p. 1348-1361.

8. Hussain, M.E. and M. Haque, Empirical Analysis of the Relationship between Money Supply and Per Capita GDP Growth Rate in Bangladesh. Journal of Advances in Economics and Finance, 2017. 2(1): p. 54.

9. Murty, K.S., K. Sailaja, and W.M. Demissie, The Long-Run Impact of Bank Credit on Economic Growth in Ethiopia: Evidence from the Johansen's Multivariate Cointegration Approach. European Journal of Business and Management, 2012. 4(14): p. 20-33.

10. Sun, G., The impact of monetary policy on economic development: Evidence from Lao PDR. 2017.

11. Otolorin, G.E. and P.E. Akpan, Effectiveness of Monetary Policy Transmission Channels in a Recessed Economy. 2017.

12. Hussain, M.E. and M. Haque, Empirical Analysis of the Relationship between Money Supply and Per Capita GDP Growth Rate in Bangladesh. Journal of Advances in Economics and Finance, 2017. 2(1): p. 55.

13. He, Y., A Study on the Relationship between Money Supply and Macroeconomic Variables in China. Mediterranean Journal of Social Sciences, 2017. 8(6): p. 99-107.

14. Patrick, C.M. and O.A. Akanbi, The relative importance of the channels of monetary policy transmission in a developing country: The case of Zambia. African Journal of Economic Review, 2017. 5(2): p. 149-174.

15. Ufoeze, L.O., Effect of monetary policy on economic growth in Nigeria: An empirical investigation. Annals of Spiru Haret University, Economic Series, 2018. 9(1): p. 123-140.

16. Tran, N., The long-run analysis of monetary policy transmission channels on inflation: a VECM approach. Journal of the Asia Pacific Economy, 2018. 23(1): p. 17-30.

17. Sims, C.A., Macroeconomics and reality. Econometrica: Journal of the Econometric Society, 1980: p. 1-48.

18. Sargent, T.J., Estimation of dynamic labor demand schedules under rational expectations. Journal of Political Economy, 1978. 86(6): p. 1009-1044.

19. Dickey, D.A. and W.A. Fuller, Distribution of the estimators for autoregressive time series with a unit root. Journal of the American statistical association, 1979. 74(366a): p. 427-431.

20. Armstrong, J.S., Principles of forecasting: a handbook for researchers and practitioners. Vol. 30. 2001: Springer Science \& Business Media.

21. Kamal, K.M.M., An ECM approach for long run relationship between real exchange rate and output growth: Evidence from Bangladesh. Dhaka University Journal of Science, 2015. 63(2): p. 105-110.

22. NIBEZA, S. and W. Tumusherure, The Impact of Monetary Policy on Rwanda's Economy: Analysis of Vector Error correction Model (1980-2006). International Journal of Contemporary Applied Sciences, 2015. 2(5): p. 12-28. 